\title{
COLD PLASTIC DEFORMATION OF PROCESSES IN CONDITIONS OF BORDER FORMATION
}

\author{
Vasyl Muzychuk, PhD of Eng., Associate Professor \\ Vinnytsia National Agrarian University
}

Музичук Василь Іванович, к.т.н., доцент

Вінницький національний аграрний університет

The article considers the process of forming the inner slot profile on a pipe billet by the method of cold plastic deformation, by compressing them with a matrix on a profile slotted mandrel (by the method of "covering" drawing). A comprehensive study of the mechanics of shaping products to assess their quality and study the possibility of improving the process itself.

In the case of three-dimensional molding, the surface of plasticity depends on the history of deformation, which is determined by the change in the stress state with increasing accumulated intensity of deformation. The surface of plasticity in this case is not fixed and can be constructed using the criterion of deformability, which provides the position of the point of the fracture surface, taking into account the history of deformation.

The planes of deformation and boundary surfaces of plasticity are constructed, which showed a sufficient margin of plasticity for the process of forming the inner splined profile.

It is substantiated that when constructing the load trajectory in the space of dimensionless indicators $\eta$ and $\chi$ its type is unambiguously determined by the conditions of formation characteristic of the studied process and practically does not depend on the mechanical properties of the deformed metal.

The areas of deformation closest to the failure are determined by indicators that take into account the influence of the first and third invariants of the stress tensor (lateral region and area of depressions of the profile relative to the process of forming the internal splined profile), in which the used plasticity reaches values $\psi=0,34 \ldots 0,4$.

From the point of view of providing a margin of safety, such calculations must be performed taking into account the indicator that takes into account the influence of the third invariant of the stress tensor.

Key words: forming, workpiece, plastic deformation, splined mandrel, plasticity reserve, load trajectory, stress tensor invariants, plasticity resource.

F. 4. Fig. 7. Table. 2. Ref. 11.

\section{Problem statement}

The implementation of modern technologies, accompanied by operations in which the flow of metals with complex rheology in conditions of complex load is impossible without scientifically sound process parameters that ensure the quality of products. The emergence of new methods of pressure treatment is constrained by a number of problems: the loss of resistance to plastic deformation, the destruction of the metal of the workpieces in the process of their deformation, the growth of metal grains after heat treatment.

These problems can be solved using the phenomenological theory of deformability of metals without destruction, which was developed at the end of the last century, which allows to estimate the marginal deformation, used plasticity, marginal deformation, and predict technological heredity (residual ductility, size grains after cold plastic deformation and subsequent heat treatment and other factors).

Phenomenological theories, based on the hypothesis of the dependence of plasticity on the history of loads, which is given in the stress space, are widely used in technological practice.

The characteristics of the stress state can be its indicators, which allow to study the trajectories of loads not in the space of the stress tensor, but in the space of its invariants.

It is of practical interest to conduct research, the results of which allow us to evaluate the applicability of plasticity diagrams constructed under conditions of flat or linear stress states to assess the deformability of metals deformed under volumetric stress conditions. The solution to this problem is associated with the difficulties that arise when conducting special experiments in high-pressure chambers. 


\section{Analysis of recent research and publications}

In the works $[1,2]$ it is shown that the dependence of plasticity on the stress state scheme can be characterized by two indicators of the stress state. In the case of a volumetric stress state, it is necessary to take into account the effect on the plasticity of the third invariant of the stress tensor [3], the results of researches of dependence of plasticity on invariants of stress tensor at hydrostatic processing of metals, and also a technique of construction of the volume diagram of plasticity for conditions of volume stress are presented. The given results of the specified works allow to estimate boundary deformation in case of volume formation under conditions under usual diagrams. $\eta=$ const, $\chi=$ const, $H=0$ (parameter characterizing the trajectory of the deformation curvature).

In traditional research, the load process is set by six time functions $\sigma_{i j}(t)$, or five functions $S_{i j}(t)$ and an independent function of time $\sigma(t)$, which leads to the need to study a large number of trajectories. It is established that under the same conditions the formation of the load trajectory for different materials may be different, this requires additional research and the creation of a cumbersome mathematical apparatus to describe each of the processes.

In connection with the above, to specify the trajectory in the stress space, it is proposed to use two dimensionless indicators of the stress state [3]:

$$
\eta=\frac{I_{1}\left(T_{\sigma}\right)}{\sqrt{3 I_{2}\left(D_{\sigma}\right)}}=\frac{\sigma_{1}+\sigma_{2}+\sigma_{3}}{\sigma_{u}} ; \chi=\frac{\sqrt[3]{I_{3}\left(T_{\sigma}\right)}}{\sqrt{3 I_{2}\left(D_{\sigma}\right)}}=\frac{\sqrt[3]{\sigma_{1} \sigma_{2} \sigma_{3}}}{\sigma_{u}} .
$$

The main advantage of the approach, in which the load trajectory is set not in the six-dimensional stress space, but in the space of dimensionless indicators $\eta$ and $\chi$ is that in the latter case, the type of load trajectory is uniquely determined by the conditions of formation characteristic of the process under study, and practically does not depend on the mechanical properties of the deformed metal. This provides ample opportunities for computer modeling and selection of the optimal material for the product, for which it is necessary to know the parameters of the coefficients of approximation of the flow curve and the surface of ultimate plasticity. In addition, this approach significantly reduces the number of time-consuming experimental studies.

Another advantage is that as shown in the works $[4,5,6]$, and also in researches on the given work properties of research materials have little influence on ways of deformation in dangerous areas (the areas closest to destruction) - deviations make no more $5 \%$, which is consistent with the results presented in the works for the processes of deposition, transverse extrusion, cold planting, etc.

Having constructed deformation paths for the hazardous area of one test material, it is possible to plot the plasticity diagrams of other materials in the same coordinate system, and to determine the total used plasticity resource, ie the expediency of material selection for this process.

\section{Purpose of the research}

To consider the process of forming the inner slot profile on the pipe blank by the method of cold plastic deformation. Calculate the limit deformations that take into account the influence of invariants of the stress tensor on the resource of plasticity in dangerous areas of deformation during the formation of workpieces, not the monotonicity of the load and not the linearity of the accumulation of damage.

\section{Results of research}

Consider the process of forming the inner slot profile on the pipe billet by cold plastic deformation. The Institute of Superhard Materials of the Academy of Sciences of Ukraine has developed a technological process of forming internal slots in pipe blanks by compressing them with a matrix on a profile slotted mandrel (by the method of "covering" drawing) [7].

The essence of the process (Fig. 1) is that the pipe blank 1 together with placed inside with a minimum gap slotted mandrel 2 on the guide sleeve 3 is pushed by the punch 4 through the deforming matrix 5, which is located together with the guide sleeve in the holder 6 . After crimping along the entire length of the product, the mandrel is extruded. In this way, formed a rectangular splined profile corresponding to the profile of the bushing shaft bushing of the steering of the car GAZ-3307. 


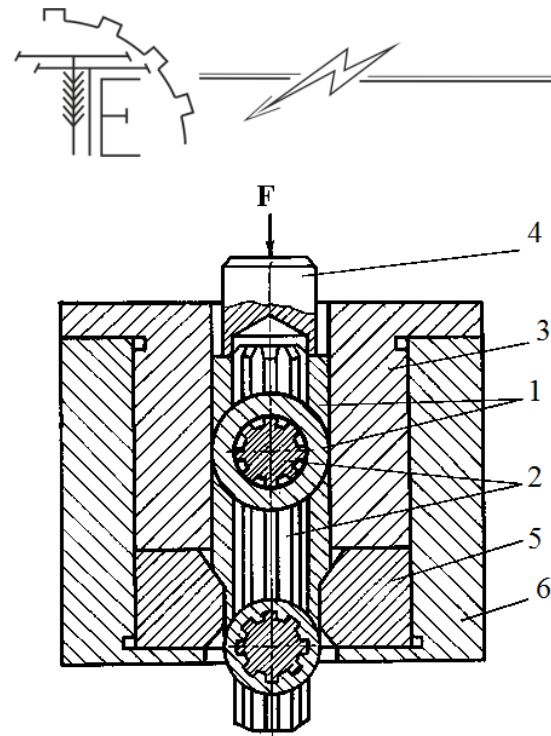

Fig. 1. Scheme of the process of forming internal slots in pipe blanks

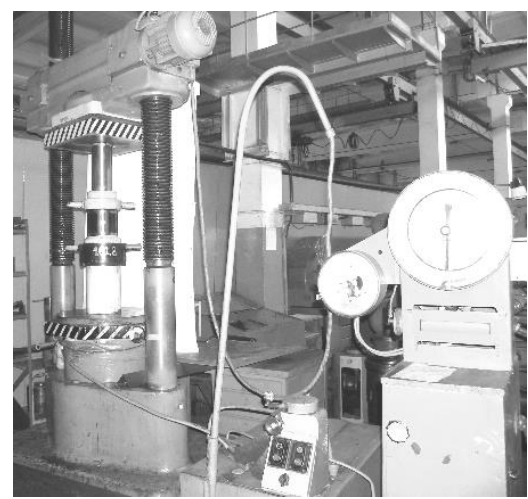

a)

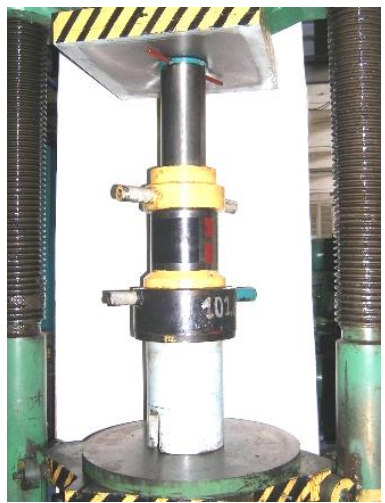

b)

Fig. 2. The equipment for reduction of splined plugs established on hydraulic press model IPS-200: a - general view; $b$-working position

The process can be performed on vertically-extended machines or hydraulic presses (Fig. 2) and is recommended as a high-performance, which allows to obtain slotted sleeves of high accuracy without further finishing in mass production.

In the process of forming the inner slot profile on the billet by cold plastic deformation axial and radial forces reach the order of $250 \mathrm{kN}$, and contact pressures of $1 \mathrm{GPa}$, which can adversely affect the durability of equipment and facilities. The slotted mandrel is made solid, so if you make slots or damage one of them, it is unsuitable for further use. It is known that the cold plastic deformation treatment reduces the surface roughness, increases its hardness and wear resistance, creates residual stresses of the required sign, the volume plastic deformation of the entire thickness of the part, which increases its strength. However, with increasing strength characteristics of the material (tensile strength $\sigma_{s}$, yield strength $\sigma_{m}$, hardness $H B$ ) there is a decrease in plastic characteristics (relative elongation $\delta$ and relative narrowing $\psi$ ).

Based on the above, we can conclude that for the process of forming the inner slot profile on the pipe blank by cold plastic deformation, it is important to comprehensively study the mechanics of forming products with an assessment of their quality and study the possibility of improving the process.

In the case of three-dimensional molding, the surface of plasticity depends on the history of deformation, which is determined by the change in the stress state with increasing accumulated intensity of deformation. The surface of plasticity in this case is not fixed and can be constructed using the criterion of deformability, which may include the position of the point of the fracture surface, taking into account the history of deformation.

Assessment of technological strength can be carried out if the dependence is known $\eta$ from the accumulated degree of deformation in the most dangerous area of the deformable workpiece, the magnitude of the characteristic deformation and other process parameters. The latter affect the stress and strain in this area. Such parameters when pressing the slot are the angle of the tooth profile, contact friction, the type of lubricant and others.

The analysis of the stress state showed [8] that the most dangerous are the contact areas of the mandrel slot and the plastic area and the area of growth (represented by a semicircle under the slot), as shown in Fig. 3. In dangerous areas, the stress parameter reaches the highest (including the sign) value, so this area is the most severe. In the course of research the movement of points of dangerous areas in the physical plane was studied by means of modeling on component samples and in the plane of indicators. $\bar{e}_{i} ; \eta ; \chi[6]$. Thus, for point 1 , the initial position was taken as shown in Fig. 3.

Table 1

Parameters of the deformation path of point 1 and area growth

\begin{tabular}{|c|c|c|c|c|c|c|}
\hline \multirow{2}{*}{ Point 1 } & $e_{i}$ & 0,28 & 0,3 & 0,35 & 0,4 & 0,45 \\
\cline { 2 - 7 } & $\eta$ & $-1,42$ & $-1,45$ & $-1,47$ & $-1,49$ & $-1,5$ \\
\hline $\begin{array}{c}\text { Region } \\
\text { outgrowth } \\
\text { formation }\end{array}$ & $e_{u}$ & 0,0045 & 0,2 & 0,28 & 0,33 & 0,45 \\
\cline { 2 - 7 } & $\eta$ & $-1,5$ & $-1,5$ & $-1,5$ & $-1,5$ & $-1,5$ \\
\hline
\end{tabular}




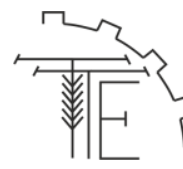

Vol. 112, No 1 / 2021

When pressed to the depth $h=1,5 \mathrm{~mm}$ point 1 falls into point 2 , with the parameters $e_{\mathrm{i}}=0,28 ; \sigma_{\mathrm{i}}=$ $610 \mathrm{MPa} ; \sigma_{0}=-290 \mathrm{MPa} ; \eta=-1,42$. In subsequent indentations, point 1 passes sequentially to points 3,4 and 5, which limit the area of growth. Data for the construction of the deformation path are given in table 1, which also presents data for the area of growth.

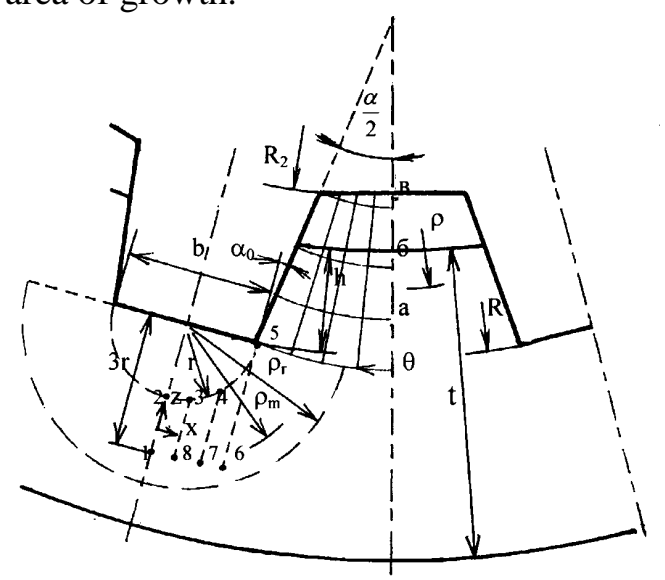

Fig. 3. Calculation scheme for determining the stress-strain state during the formation of the internal spline profile

Table 2 presents the calculation data for the construction of the surface (deformation plane) for points $1,2,5$, taking into account their movement in the physical plane.

Table 2

Data for the construction of the deformation plane for points 2, 5

\begin{tabular}{|c|c|c|c|c|c|c|c|c|}
\hline \multicolumn{2}{|c|}{ Calculation results for point 2} \\
\hline h, mm & $e_{u}$ & $\begin{array}{c}\sigma_{u} \\
\mathrm{MPa}\end{array}$ & $\begin{array}{c}\sigma_{\rho} \\
\mathrm{MPa}\end{array}$ & $\begin{array}{c}\sigma_{\theta} \\
\mathrm{MPa}\end{array}$ & $\begin{array}{c}\sigma_{0} \\
\mathrm{MPa}\end{array}$ & $\eta$ & $\begin{array}{c}\tau_{\rho \theta} \\
\mathrm{MPa}\end{array}$ & $\chi$ \\
\hline 1,5 & 0,28 & 610 & 0 & -600 & -305 & $-1,5$ & 90 & 0,22 \\
\hline 1,7 & 0,32 & 620 & 100 & -510 & -200 & -1 & 77 & 0,366 \\
\hline 1,8 & 0,35 & 630 & 120 & -510 & -190 & $-0,92$ & 76 & 0,374 \\
\hline 2,3 & 0,4 & 650 & 160 & -490 & -160 & $-0,75$ & 73 & 0,37 \\
\hline 2,7 & 0,45 & 660 & 180 & -480 & -150 & $-0,67$ & 71 & 0,36 \\
\hline \multicolumn{7}{|l|}{ The results of the calculation for point 5 } \\
\hline 1,5 & 0,13 & 550 & 120 & -430 & -150 & $-0,83$ & 74 & 0,373 \\
\hline 1,8 & 0,28 & 610 & 160 & -430 & -138 & $-0,7$ & 69 & 0,35 \\
\hline 2 & 0,33 & 630 & 180 & -450 & -130 & $-0,63$ & 67 & 0,36 \\
\hline 2,4 & 0,4 & 650 & 240 & -410 & -85 & $-0,4$ & 61 & 0,316 \\
\hline 2,7 & 0,45 & 660 & 300 & -360 & -13 & $-0,13$ & 54 & 0,226 \\
\hline
\end{tabular}

The starting position of point 2 was the distance $r$ (Fig. 3). When pressed to the depth $h=1,5 \mathrm{~mm}$ it falls at the beginning of the converging channel. Subsequent calculation for point 2 was performed, as for the mobile, on the border of the converging channel. For point 5 , the calculation was performed as for the mobile, from the beginning to the end of the converging channel.

For the areas closest to the destruction, ways of deformation of characteristic points were built: $1-1$; $2-2 ; 5-5 ; \mathrm{n}-\mathrm{n}$ (growth) (Fig. 4). 


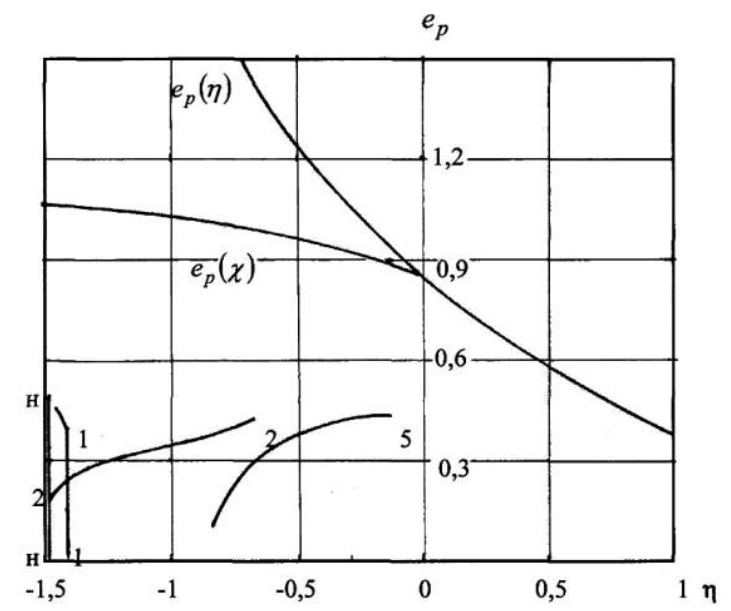

Fig. 4. Diagram of plasticity of steel $20 \mathrm{X}$ and ways of deformation dangerous areas when pressing the slotted stamp

As can be seen from Fig. 4 areas 2-2; 5-5 have complex deformation pathways, so we applied criteria based on the nonlinear theory of damage accumulation, which take into account the history of deformation in the form [9]:

$$
\psi=\int_{0}^{e_{i}} n \frac{e_{i}^{n-1}}{e_{p}(\eta)^{n}} d e_{i}=1,
$$

where $n=1+0,2 \frac{d \eta}{d e_{i}} ; e_{p}\left(e_{i}\right)$ - the value of the plasticity diagram, which corresponds to the value $e_{i}$ path of deformation, as well as a criterion that takes into account the tensor nature of the accumulation of damage [10]:

$$
\begin{aligned}
& \psi_{i j}=\int_{0}^{e_{i}}\left(1-a+2 a \frac{e_{i}}{e_{p}(\eta)}\right) \beta_{i j} \frac{d e_{i}}{e_{p}(\eta)} ; \\
& \psi_{i j} \psi_{i j}=1 \text {, }
\end{aligned}
$$

where $\beta_{i j}=\sqrt{\frac{2}{3}} \frac{d \varepsilon_{i j}}{e_{i}}-$ guide tensor of strain rates; $a=$ const - some coefficient that is selected to satisfy condition (4), which is taken as the condition of destruction.

In fig. 5 presents the results of the calculation of stress indicators $\eta$ and $\chi$ and the used plasticity resource along the contact line of the slot of the mandrel and the plastic region, as well as the discrepancy of the calculation results $\psi(\chi), \psi(\eta), \psi_{i j}(\chi), \psi_{i j}(\eta)$.

These studies are more widely presented in $[6,8]$.

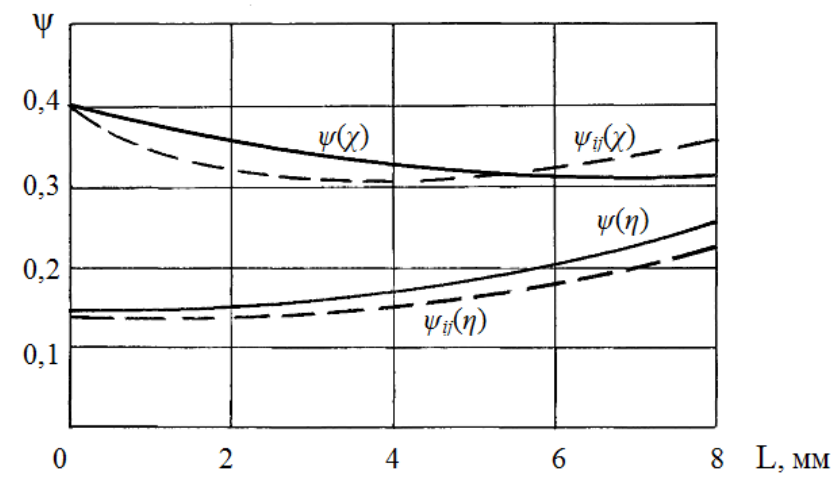

Fig. 5. Discrepancy of calculation results $\psi(\chi), \psi(\eta)$ - by criterion (2);

$$
\psi_{i j}(\chi), \psi_{i j}(\eta) \text { - by criterion (3); }
$$




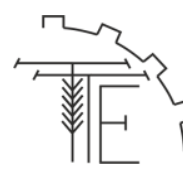

From the graphical data it follows that the values of the used resource of plasticity, calculated taking into account the impact $I_{3}\left(T_{\sigma}\right)$, appeared at different values $\eta$ higher values $\psi$, calculated without taking it into account. The magnitude of the discrepancy depends on the indicators $\eta$ i $\chi$. With a decrease $\eta$ (increasing hydrostatic pressure) increases the impact $I_{3}\left(T_{\sigma}\right)$ by the magnitude of the ultimate deformation. It should be noted that at certain levels of hydrostatic pressure, when its value modulo approaches the yield strength of the material on the displacement, the effect $I_{3}\left(T_{\sigma}\right)$ decreases. Further increases in pressure are likely to increase the impact again $I_{3}\left(T_{\sigma}\right)$.

In fig. 6 and 7 show the planes of deformation and the boundary surfaces of plasticity for points 2 and 5 .

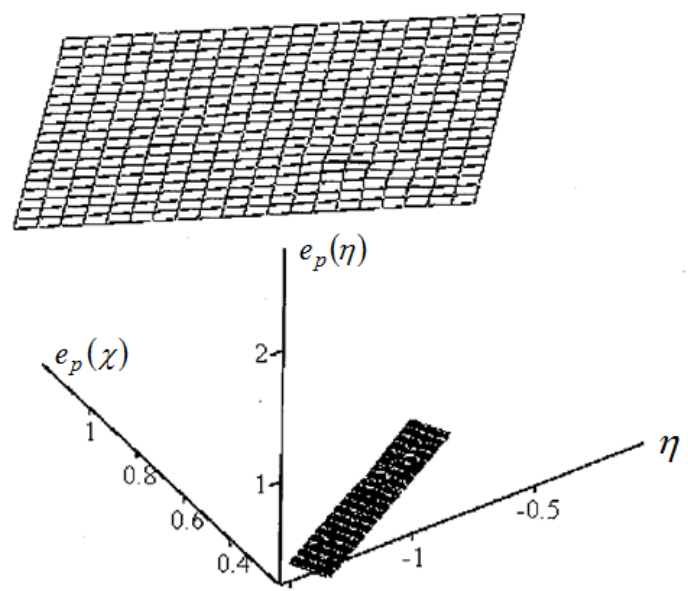

Fig. 6. The plane of deformation of the point 2 $\left(\bar{e}_{u}=f(\eta, \chi)\right)$ and marginal surface $e_{p}=f(\eta, \chi)$
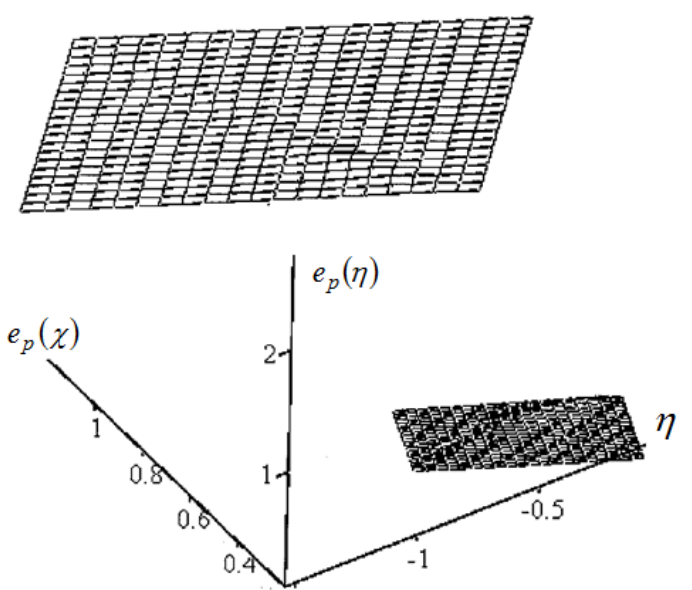

Fig. 7. The plane of deformation of the point 5 $\left(\bar{e}_{i}=f(\eta, \chi)\right)$ and marginal surface $e_{p}=f(\eta, \chi)$

As shown in Fig. 6 and 7 the plasticity boundary surfaces for points 2 and 5 indicate a sufficient margin of plasticity of the products.

\section{Conclusions}

1. The constructed deformation planes and boundary surfaces of plasticity showed a sufficient margin of plasticity for the process of forming the inner spline profile.

2. It is substantiated that when constructing the load trajectory in the space of dimensionless indicators $\eta$ i $\chi$ its type is unambiguously determined by the conditions of formation characteristic of the studied process and practically does not depend on the mechanical properties of the deformed metal.

3. The areas of deformation closest to the failure are determined by indicators that take into account the influence of the first and third invariants of the stress tensor (lateral region and area of depressions of the profile relative to the process of forming the internal splined profile), in which the used plasticity reaches values $\psi=0,34 \ldots 0,4$. From the point of view of providing a safety margin, such calculations must be performed taking into account the indicator that takes into account the influence of the third invariant of the stress tensor.

4. Investigating the processes of cold plastic formation, co-accompanied by complex non-monotonic deformation, it is necessary to apply models that take into account the nonlinear nature of the accumulation of damage.

\section{References}

[1] Kolmogorov, V. L. (1970). Napryazheniye. Deformatsii. Razrusheniye [Voltage. Deformations. Destruction]. M: Metallurgy. [in Rassian].

[2] Ogorodnikov, V. A., Sivak I. O. (1982). Issledovaniye protsessov slozhnogo deformirovaniya v malootkhodnoy tekhnologii ob"yomnoy shtampovki [Research of complex deformation processes in low-waste technology of forging]. Tr. Republic of NTK "Modern methods of low-waste and waste-free technology in mechanical engineering". Kishinev. 122-123. [in Belarus].

[3] Ogorodnikov, V. A. (1983). Otsenka deformiruyemosti metallov pri obrabotke davleniyem [Assessment of the deformability of metals during pressure treatment]. K: Vyshcha shkola. [in Ukrainian].

[4] Ogorodnikov, V. A. (1989). Deformiruyemost' i razrusheniye metallov pri plasticheskom formoizmenenii. 


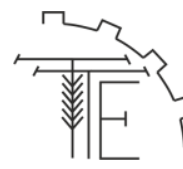

[Deformability and fracture of metals during plastic deformation]. K: UMK 130. [in Ukrainian].

[5] Ohorodnikov, V. A., Muzychuk, V. I., Nakhaychuk, O. V. (2007). Mekhanika protsesiv kholodnoho formozminyuvannya z odnotypnymy skhemamy mekhanizmu deformatsiyi. Monohrafiya [Mechanics of cold forming processes with the same type of deformation mechanism schemes. Monograph]. V: UNIVERSUMVinnytsya [in Ukrainian].

[6] Nakhaychuk, O. V., Rosenberg, O. O., Ogorodnikov, V. A., Kritsky, A. D., Melnichenko, V. V., Studenets, S. F. (2008). Novi tekhnolohichni protsesy $\mathrm{z}$ vykorystannyam prohresyvnykh metodiv plastychnoho deformuvannya. Monohrafiya [New technological processes using advanced methods of plastic deformation. Monograph]. V: UNIVERSUM-Vinnytsya [in Ukrainian].

[7] Rosenberg, O. A, Trachenko, B. P. (1991). Formoobrazovaniya shlitsevikh otverstiy v trubnykh zagotovkakh metodom kholodnogo plasticheskogo deformirovaniya [Forming of spline holes in pipe blanks by cold plastic deformation]. Technology and organization of production, 2. 20-30 [in Ukrainian].

[8] Ogorodnikov, V. A., Savchinsky, I. G., Nakhaichuk, O. V. (2004). Napryazhonno-deformirovannoye sostoyaniye pri formirovanii vnutrennego shlitsevogo profilya metodom obzhatiya na opravke [Stress-strain state during the formation of an internal spline profile by the method of compression on a mandrel]. Heavy engineering, 12.31-33. [in Rassian].

[9] Ohorodnikov, V. A., Nakhaychuk, O. V., Muzychuk, V. I. (2005). Prilozheniye teorii deformiruyemosti k resheniyu zadach mekhaniki formirovaniya vnutrennego shlitsevogo profilya obzhatiyem na opravke [Application of the theory of deformability to solving the problems of mechanics of forming an internal spline profile by compression on a mandrel]. Progressive technologies and equipment for forging and stamping production. Moscow: MSTU "MAMI". 66-75. [in Rassian].

[10] Syvak, R. I. (2015). Plastychnist' metaliv pry nemonotonnomu navantazhenni [Plasticity of metals at nonmonotonic loading]. Tekhnika, enerhetyka, transport APC. Vinnytsya, 1(91). 108-111 [in Ukrainian].

[11] Sivak, R. I. (2017). Evaluation of metal plasticity and research on the mechanics of pressure treatment processes under complex loading. Eastern-European journal of enterprise technologies, 6/7(90). 34-41. [in English].

\section{ХОЛОДНЕ ПЛАСТИЧНЕ ДЕФОРМУВАННЯ ЗАГОТОВОК В УМОВАХ ГРАНИЧНОГО ФОРМОУТВОРЕННЯ}

В статті розглянуто процес формоутворення внутрішнього шліџьового профілю на трубній заготовиі методом холодного пластичного деформування, шляхом їх обтиску матрищею на профільну шлічьову оправку (методом “охоплюючого” протягування). Проведено всебічне вивчення механіки формоутворення виробів і проведення оцінки їх якості та дослідження можливості вдосконалення самого проиесу.

У випадку об'ємного формоутворення поверхня пластичності залежить від історії деформування, яка визначається зміною показників напруженого стану при зростанні накопиченої інтенсивності деформачій. Поверхня пластичності в изьому випадку не є фіксованою і може бути побудована за допомогою критерію деформуємості, який передбачає положення точки поверхні руйнування з врахуванням історї деформування.

Побудовані площини деформування $і$ граничні поверхні пластичності, які показали на достатній запас пластичності для прочесу формоутворення внутрішнього шліщьового профілю.

Обтрунтовано, що при побудові траєкторії навантаження в просторі безрозмірних показників $\eta i \chi$ iї вид однозначно визначається умовами формоутворення, характерними для досліджуваного процесу і практично не залежить від механічних властивостей деформованого металу.

Визначені області деформування, найбільш близькі до руйнування за показниками, які враховують вплив першого та третього інваріантів тензора напружень (бокова область та область впадин профілю стосовно процесу формування внутрішнього иліцьового профілю), в яких використаний ресурс пластичності досягає значень $\psi=0,34 \ldots 0,4$.

3 точки зору забезпечення запасу міџності подібні розрахунки необхідно проводити 3 врахуванням показника, який враховує вплив третього інваріанта тензора напружень.

Ключові слова: формоутворення, заготовка, пластичне деформування, шлічьова оправка, запас пластичності, траєкторія навантаження, інваріанти тензора напружень, ресурс пластичності.

Ф. 4. Рис. 7. Табл. 2. Літ. 11. 


\title{
№ 1 (112)/2021 \\ Vol. 112, No 1 / 2021 \\ Техніка, енергетика, транспорт АПК \\ ХОЛОДНОЕ ПЛАСТИЧЕСКОЕ ДЕФОРМИРОВАНИЕ ЗАГОТОВОК В УСЛОВИЯХ ПРЕДЕЛЬНОГО ФОРМООБРАЗОВАНИЯ
}

В статье рассмотрен процесс формообразования внутреннего шлицевого профиля на трубной заготовке методом холодного пластического деформирования, путем их обжатия матрицей на профильную шлицевую оправку (методом "охватывающего" протягивания). Проведено всестороннее изучение механики формообразования изделий по проведению оценки их качества и исследования возможности совершенствования самого прочесса.

В случае объемного формообразования поверхность пластичности зависит от истории деформирования, которая определяется изменением показателей напряженного состояния при росте накопленной интенсивности деформащий. Поверхность пластичности в этом случае не является фиксированной и может быть построена с помощью критерия деформируемости, который предусматривает положение точки поверхности разрушения с учетом истории деформирования.

Построенные плоскости деформирования и предельные поверхности пластичности, которые показали на достаточный запас пластичности для процесса формообразования внутреннего шлицевого профиля.

Обосновано, что при построении траектории нагрузки в пространстве безразмерных показателей и ее вид однозначно определяется условиями формообразования, характерными для исследуемого процесса и практически не зависит от механических свойств деформированного металла.

Определены области деформирования, наиболее близкие к разрушению по показателям, которые учитывают влияние первого и третьего инвариантов тензора напряжений (боковая область и область впадин профиля относительно проиесса формирования внутреннего шлицевого профиля), в которых использован ресурс пластичности достигает значений $\psi=0,34 \ldots 0,4$.

С точки зрения обеспечения запаса прочности подобные расчеты необходимо проводить с учетом показателя, который учитывает влияние третьего инварианта тензора напряжений.

Ключевые слова: формообразование, заготовка, пластическое деформирование, илицевая оправка, запас пластичности, траектория нагрузки, инварианты тензора напряжений, ресурс пластичности.

Ф. 4. Рис. 7. Табл. 2. Лит. 11.

\begin{abstract}
ABOUT THE AUTHORS
Музичук Василь Іванович - кандидат технічних наук, доцент кафедри «Технологічних процесів та обладнання переробних і харчових виробництв» Вінницького національного аграрного університету (вул. Сонячна, 3, м. Вінниця, 21008, Україна, e-mail: wasil@vsau.vin.ua, https://orcid.org/0000-00020848-2943).
\end{abstract}

Музычук Василий Иванович - кандидат технических наук, доцент кафедры «Технологических процессов та оборудования перерабатывающих та пищевых производств» Винницкого национального аграрного университета (ул. Солнечная, 3, г. Винница, 21008, Украина, e-mail: wasil@vsau.vin.ua, https://orcid.org/0000-0002-0848-2943 ).

Vasyl Muzychuk - PhD, Associate Professor of the Department of "Technological Processes and Equipment of Processing and Food Productions" of the Vinnytsia National Agrarian University (3 Solnechnaya St, Vinnytsia, 21008, Ukraine, e-mail: wasil@ vsau.vin.ua, https://orcid.org/0000-0002-0848-2943 ). 